\title{
NeW Ways and Means to StRengthen the RESPONSIBLE AND PEACEFUL USE OF OUTER SPACE
}

David Kuan-Wei Chen*

TABLE OF CONTENTS

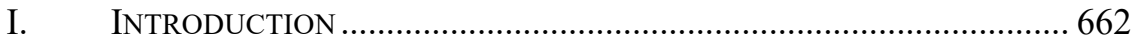

II. LEGAL REGIME GOVERNING SPACE .................................................. 663

III. The Legal LACUNAE With REgARD to RESPONSIBLE AND

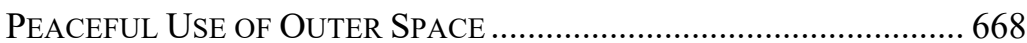

IV. INTERNATIONAL EFFORTS TO STRENGTHEN THE RESPONSIBLE AND

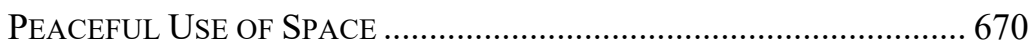

V. Ways and Means of Maintaining OUter Space for Peaceful

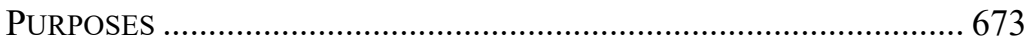

VI. The LONG-TERm SustainABILITY GUIDELINES .............................. 674

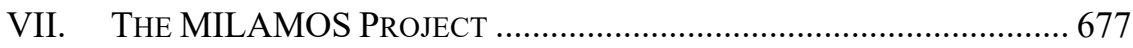

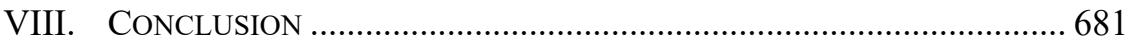

\footnotetext{
* Executive Director, Centre for Research in Air and Space Law, McGill University. This Article is based on remarks delivered at "The Future of Space Governance" conference held in Athens, Georgia, at the University of Georgia School of Law on October 28, 2019 and a presentation delivered at the UN/Turkey/APSCO Conference on Space Law and Policy in Istanbul, Turkey, September 23-26, 2019, titled "The Role of International Manuals in Contributing to the Peaceful and Safe Use of Outer Space.” The author would like to acknowledge the valuable comments and suggestions of Professor Ram Jakhu. All errors and omissions of course remain that of the author.
} 


\section{INTRODUCTION}

There is a growing unease in space, and on Earth. ${ }^{1}$ Fueled by rising geopolitical tensions on Earth ${ }^{2}$ and growing rhetoric on the inevitability of a war in space, ${ }^{3}$ humanity stands at a crucial turning point and a crossroads: Do we continue to collectively reap the economic, technological, scientific, social, and strategic benefits that space activities and assets have to offer, ${ }^{4}$ or do we choose to weaponize the "ultimate high ground"5 and direct space assets as instruments of destruction in ways unimaginable? ${ }^{6}$

1 As the U.S. Representative to the First Committee of the General Assembly succinctly argued in 1962:

Outer space is not a new subject, it is just a new place in which all the old subjects come up. The things that go on in space are intimately related to the things that go on here on earth. It would be naive to suppose that we can insulate outer space from other aspects of human existence.

See Contemporary Practice of the United States Relating to International Law, 57 AM. J. OF INT'L L. 403, 429 (1963).

2 Among which are tensions in the South China Sea and Taiwan Strait, the unilateral withdrawal from the Anti-Ballistic Missile Treaty (2002) and more recently the events in Syria and ongoing trade war between the United States and the People's Republic of China.

3 Stuart Clark, It's Going to Happen: Is the World Ready for a War in Space?, GUARDIAN (Apr. 15, 2018), www.theguardian.com/science/2018/apr/15/its-going-to-happ en-is-world-ready-for-war-in-space; see also Steven Freeland, Star Wars: The Battle for Laws Against War in Outer Space, Austl. Inst. InT'L AfF. (Apr. 4, 2018), http://www.inte rnationalaffairs.org.au/australianoutlook/star-wars-law-in-outer-space/.

${ }^{4}$ See Benefits of Space for Humankind, United Nations Office for Outer Space AFF., https://www.unoosa.org/oosa/en/benefits-of-space/benefits.html (last visited Feb. 22, 2020); see generally Jeff Greenblatt \& Al Anzaldua, How Space Technology Benefits the Earth, SPACE REV. (July 29, 2019), https://www.thespacereview.com/article/3768/1.

5 After the launch of Sputnik, U.S. Air Force Chief of Staff General Thomas D. White was quoted as saying "I feel that in the future whoever has the capability to control space will likewise possess the capability to control the surface of the Earth." ROBERT F. Futrell, Ideas, Concepts, Doctrine: Basic Thinking in the United States Air Force 550 (1989). Fast forward to 2019, United States President Trump noted that there are those who "seek to challenge [the U.S.] in the ultimate high ground of space." Remarks by President Trump at Event Establishing the U.S. Space Command, White House (Aug. 29, 2019), https://www.whitehouse.gov/briefings-statements/remarks-president-trump-eventestablishing-u-s-space-command/.

${ }^{6}$ Writing already in the early 1980 s, Bhupendra Jasani warned that: "The militarization of outer space has reached such a level that loss of some or all of a nation's military spacecraft would reduce considerably the efficiency of that nation's fighting forces on Earth. Therefore war in space would be just an indication of initiation of a war on Earth . ..."

See Bhupendra Jasani, Space: Battlefield of the Future 444 (1982). A space war "could very well end with a crippled global economy, inoperable infrastructure, and a planet shrouded by the orbiting fragments of pulverized satellites" Garrett M. Graff, The New Arms Race Threatening to Explode in Space, WIRED (June 26, 2018), https://www.wir ed.com/story/new-arms-race-threatening-to-explode-in-space/. 
Space systems perform a myriad of civilian weather monitoring, communications, navigation, and facilitate the provision of humanitarian and emergency relief efforts. ${ }^{7}$ The sustainable and responsible use of space is, however, increasingly fragile, threatened by intensified research and potential deployment of a whole host of disabling or destructive ways and means. These range from electronic warfare (jamming and spoofing of transmissions), cyber-attacks, directed energy attacks (from the ground, air, sea, or space-based platforms), to orbital-based anti-satellite systems, and ground-based anti-satellite weapons. ${ }^{8}$

Indeed, high on the agenda at the United Nations (UN) for decades is the concern of an arms race in outer space, ${ }^{9}$ and the placement (and arguably use) of weapons in outer space that would pose a "grave danger for international peace and security." ${ }^{10}$ This Article will provide an overview of adequacy of the legal framework in securing the responsible and peaceful use of outer space, and long-standing diplomatic efforts to prevent the extension of arms into the final frontier. Specifically, it will turn attention to the recently adopted UN Long-Term Sustainability Guidelines, ${ }^{11}$ as well as civil society initiatives, such as the McGill Manual on International Law Applicable to Military Uses of Outer Space (McGill Manual, or MILAMOS), which aim to increase transparency and strengthen the rule of law in a domain space where scientific, economic and strategic interest invariably intercept and intertwine. ${ }^{12}$

\section{LEGAL REGIME GOVERNING SPACE}

Outer space has never been a lawless domain of human activity, but has always been subject to international law. ${ }^{13}$ As soon as activities of states entered the realm of outer space, the overarching regime of international law that

${ }^{7}$ Int'l Comm. of the Red Cross, Humanitarian Consequences and Constraints Under International Humanitarian Law (IHL) Related to the Potential Use of Weapons in Outer Space, I 3, U.N. Doc. GE-PAROS/2019/WP.1 (Mar. 18, 2019).

${ }^{8}$ U.N. Secretary-General, Group of Governmental Experts on Further Practical Measures for the Prevention of an Arms Race in Outer Space, \36, U.N. Doc. A/74/77, annex II (Apr. 9, 2019).

9 See, e.g., G.A. Res. 74/32, Prevention of Arms Race in Outer Space (Dec. 12, 2019). The same resolution has been adopted annually for close to four decades since 1981.

10 G.A. Res. 74/34, Further Practical Measures for the Prevention of an Arms Race in Outer Space, at pmbl., \ 3 (Dec. 12, 2019).

${ }^{11}$ Comm. on the Peaceful Uses of Outer Space, Rep. of Work of Its Sixty-Second Session, U.N. Doc. A/74/20, at 50-69 (July 3, 2019) [hereinafter Long-Term Sustainability Guidelines].

${ }^{12}$ For more information on the MILAMOS Project, please visit the dedicated MILAMOS website: www.mcgill.ca/milamos/.

13 Manfred Lachs, The Law of Outer Space: An Experience in Contemporary LAwMAKING 125 (Tanja Masson-Zwaan \& Stephan Hobe eds., Martinus Nijhoff Publishers 2010) (1972) [hereinafter LACHS, THE LAW OF OUTER SPACE] (reissued on the occasion of the 50th anniversary of the International Institute of Space Law). 
governs the rights and responsibilities of states became automatically applicable. ${ }^{14}$ These sentiments are reflected in the 1963 Declaration of Legal Principles Governing the Activities of States in the Exploration and Use of Outer Space, ${ }^{15}$ and the 1967 Outer Space Treaty,${ }^{16}$ which translated the provisions of the 1963 Declaration into a binding multilateral agreement. Article III of the Outer Space Treaty underlines that:

States Parties to the Treaty shall carry on activities in the exploration and use of outer space, including the moon and other celestial bodies, in accordance with international law, including the Charter of the United Nations, in the interest of maintaining international peace and security and promoting international co-operation and understanding. ${ }^{17}$

That space activities must be conducted in the interest of international peace and security traces its origins to the dawn of the Space Age. In 1958, almost immediately after the launch of the first artificial satellite Sputnik I, the UN General Assembly (UNGA) adopted the first resolution specifically dealing with outer space. ${ }^{18}$ Recognizing that all humankind, have a "common interest" in outer space, ${ }^{19}$ the Preamble of Resolution 1348 (XIII) underlined the importance of avoiding "the extension of present national rivalries into this new field." 20 To further "co-operation in the study of outer space for peaceful purposes," ${ }^{21}$ the UN Committee on the Peaceful Uses of Outer Space (UNCOPUOS) $)^{22}$ was established as the diplomatic forum to address and adopt

${ }^{14} I d$. Even before the space era, Oscar Schachter argued that legal principles and precedents which form customary international law are applicable to space activities. Oscar Schachter, Who Owns the Universe, in Space Law: A Symposium PrePared at the REQuest OF Honorable Lyndon B. Johnson 8, 14 (U.S. Gov't Printing Office 1959).

15 G.A. Res. 1962 (XVIII), Declaration of Legal Principles Concerning the Activities of States in the Exploration and Use of Outer Space, 9ף 2, 4 (Dec. 13, 1963) [hereinafter Declaration of Legal Principles].

16 Treaty on Principles Governing the Activities of States in the Exploration and Use of Outer Space, Including the Moon and Other Celestial Bodies, Jan. 27, 1967, 18 U.S.T. 2410, 610 U.N.T.S. 205 (entered into force Oct. 10, 1967) [hereinafter Outer Space Treaty].

17 Declaration of Legal Principles, supra note 15, at 4; and Outer Space Treaty, supra note 16 , at art III.

18 G.A. Res. 1348 (XIII), Question of the Peaceful Use of Outer Space (Dec. 13, 1958). The first resolution that incidentally alluded to space activities was adopted immediately after the launching of Sputnik I, and called for the "joint study of an inspection system designed to ensure that the sending of objects through outer space shall be exclusively for peaceful and scientific purposes.” See G.A. Res.1148 (XII), ๆ 1(f) (Nov. 14, 1957) (emphasis added).

19 G.A. Res. 1348 (XIII), supra note 18, at pmbl., $\mid 1$.

20 Id. at pmbl., 91.

${ }^{21}$ Id. at pmbl., 97.

22 Id. at 91. 
measures relating to the peaceful use of outer space. ${ }^{23}$ In the years that followed, several treaties ${ }^{24}$ and resolutions ${ }^{25}$ adopted by the UNCOPUOS would form a body of rules underpinning the global space governance system. ${ }^{26}$

The unanimously-adopted 1963 Declaration of Legal Principles resolution and the 1967 Outer Space Treaty both recognize in their respective preambles $^{27}$ "the common interest of all mankind in the progress of the exploration and use of outer space for peaceful purposes." ${ }^{28}$ The concept of "peaceful

${ }^{23}$ At the time of writing, the UNCOPUOS has grown to assume the role "as a forum for fostering dialogue and cooperation among States members of the Committee and organizations with permanent observer status and for strengthening partnerships among States, intergovernmental and non-governmental organizations, industry and private sector entities." The number of Members States of the Committee has increased from eighteen in 1958 to ninety-two Member States in 2019. See Long-Term Sustainability Guidelines, supra note 11 , at $9 \uparrow 15-16$.

${ }^{24}$ Outer Space Treaty, supra note 16; Agreement on the Rescue of Astronauts, the Return of Astronauts and the Return of Objects Launched into Outer Space, Apr. 22, 1968, 19 U.S.T. 7570, 672 U.N.T.S. 119 (entered into force Dec. 3, 1968) [hereinafter Rescue and Return Agreement]; Convention on International Liability for Damage Caused by Space Objects, Mar 29, 1972, 24 U.S.T. 2389, 961 U.N.T.S. 187 (entered into force Sept. 1, 1972) [hereinafter Liability Convention]: Convention on Registration of Objects Launched into Outer Space, opened for signature Nov. 12, 1974, 28 U.S.T. 695, 1023 U.N.T.S. 15 (entered into force Sept. 15, 1976) [hereinafter Registration Convention]; Agreement Governing the Activities of States on the Moon and Other Celestial Bodies, Dec. 5, 1979, 1363 U.N.T.S. 3 (entered into force July 11, 1984) [hereinafter Moon Agreement].

25 They are: Declaration of Legal Principles, supra note 15; G.A. Res. 37/92, Principles Governing the Use by States of Artificial Earth Satellites for International Direct Television Broadcasting (Dec. 10, 1982); G.A. Res. 41/65, Principles Relating to Remote Sensing of the Earth from Space (Dec. 3, 1986); G.A. Res. 47/68, Principles Relevant to the Use of Nuclear Sources in Outer Space (Dec. 14, 1992); G.A. Res. 51/122, Declaration on International Cooperation in the Exploration and Use of Outer Space for the Benefit and in the Interest of All States, Taking into Particular Account the Needs of Developing Countries (Dec. 13, 1996) [hereinafter Space Benefits Declaration].

26 See Ram Jakhu \& Joseph Pelton, Global Space Governance: An International STUdY (2017); see also G.A. Dec. 2/33, U.N. Doc. A/AC.105/116 (Dec. 13, 2017).

27 This does raise the issue of whether text in the preamble of an international instrument can have binding force. In South West Africa Cases, the ICJ held:

[T]he preambular parts of the United Nations Charter constitute the moral and political basis for the specific legal provisions thereafter set out. Such considerations do not, however, in themselves amount to rules of law. All States are interested - have an interest - in such matters. But the existence of an "interest" does not of itself entail that this interest is specifically juridical in character.

See South West Africa Cases (Eth. v. S. Afr.; Liber. v. S. Afr.), Judgement, 1966 I.C.J. 6, If 50 (July 18). Even so, the preamble has an important role in the interpretation of treaties. See also Vienna Convention on the Law of Treaties art. 31, May 23, 1969, 1155 U.N.T.S 331 [hereinafter Convention on the Law of Treaties or VCLT].

28 Outer Space Treaty, supra note 16, at $\uparrow 2$. Note that the Preamble of Resolution 1348 (XIII) underlined "the common aim that outer space should be used for peaceful purposes 
purpose" does not have an authoritative definition and continues to be a source of contention. ${ }^{29}$ What evolved from declarations of spacefaring states and state practice, particularly of the former Soviet Union and the United States, ${ }^{30}$ is that "peaceful purposes" means that outer space can be used both for civilian and military non-aggressive purposes. ${ }^{31}$ Thus, as long as space activities, including those conducted by the military or are in support of a strategic or military activities, are carried out in accordance with international law, including the UN Charter, then it is compatible with exploring or using space for "peaceful purposes." 32

only." G.A. Res. 1348 (XIII), supra note 18, at pmbl., ๆ 1 (emphasis added); see also id. at pmbl., 10 (reflecting text of the Antarctic Treaty, which drafted and adopted around the same time as the UN resolutions on space were adopted). Thus, Article 1 of the Antarctic Treaty reads:

1. Antarctica shall be used for peaceful purposes only. There shall be prohibited, inter alia, any measures of a military nature, such as the establishment of military bases and fortifications, the carrying out of military maneuvers, as well as the testing of any type of weapons.

2. The present treaty shall not prevent the use of military personnel or equipment for scientific research or for any other peaceful purposes.

Antarctic Treaty art. 1, June 23, 1961, 402 U.N.T.S. 71 (emphasis added). The immediate recognition of outer space as an ultimate high ground for military operations would eventually weaken the notion that outer space should be explored and used for "peaceful purposes only. See Bin Cheng, Military Use of Outer Space: Article IV of the 1967 Space Treaty Revisited, in The Utilization of THE WorlD's Air SPACE AND Free Outer Space and Free Outer Space in the $21^{\text {ST }}$ Century 305, 308 (Chia-Jui Cheng \& Doo Hwan Kim eds., 2000).

29 See, e.g., Marko G. Markoff, Disarmament and "Peaceful Purposes" Provisions in the 1967 Outer Space Treaty, 4 J. Space L. 3 (1976); Carl Q. Christol, The Modern InTERnAtional Law OF OUTER Space 20-25 (Pergamon Press 1982); Ivan A. Vlasic, The Legal Aspects of Peaceful and Non-Peaceful Uses of Outer Space, in PEACEFUL AND NONPeaceful Uses Of Space: Probs. of Definition for the Prevention of an Arms Race 37 (Bhupendra Jasani ed., 1991); Bin Cheng, Definitional Issues in Space Law: The 'Peaceful Use' of Outer Space, Including the Moon and Other Celestial Bodies, in STUDIES IN INT'L SPACE LAW 281 (1997); Elizabeth S. Waldrop, Weaponization of Outer Space: US National Policy, 29 ANNALS AIR \& SpaCe L. 329 (2004).

Though, Judge Manfred Lachs notes "there seems to be little doubt as to the real meaning of [the] words" peaceful purposes, which purport to completely disarm and demilitarise space. LACHS, THE LAW OF OUTER SPACE, supra note 13, at 97.

${ }^{30}$ Cheng, supra note 29, at 224-25; see also Vladimir Kopal, Treaty on Principles Governing the Activities of States in the Exploration and Use of Outer Space, Including the Moon and Other Celestial Bodies, U.N. AudiOviSUAL LiBR. OF INT'L L. 1 (2008), https://leg al.un.org/avl/pdf/ha/tos/tos_e.pdf.

31 This has been the position of the majority of States. See Carl Q. Christol, The Common Interest in the Exploration, Use and Exploitation of Outer Space for Peaceful Purposes: The Soviet-American Dilemma, in Proceedings of the Twenty-Seventh Colloquium ON THE LAW OF OUTER SPACE (1985).

32 Outer Space Treaty, supra note 16, at art. III. 
This understanding can be further supported by Article IV of the Outer Space Treaty, which provides that the Moon and other celestial bodies must be explored and used for "exclusively" peaceful purposes. ${ }^{33}$ The inclusion of the word "exclusive" is clarified as meaning an express prohibition of the "establishment of military bases, installations and fortifications," and an unambiguous prohibition against "the testing of any type of weapons and the conduct of military manoeuvres on celestial bodies." ${ }^{34}$ Nevertheless, military personnel, equipment, and facilities can be used for scientific research or for "peaceful exploration of the Moon and other celestial bodies."

Article IV of the Outer Space Treaty specifically prohibits states parties from placing "in orbit around the Earth any objects carrying nuclear weapons or any other kinds of weapons of mass destruction" and from installing "such weapons on celestial bodies, or station[ing] such weapons in outer space in any other manner." 36 This prohibition does not forbid the placement or stationing of conventional, non-nuclear weapons or weapons of mass destruction. $^{37}$

In effect, the Outer Space Treaty does not expressly prohibit military uses of outer space per se, and only partially de-weaponizes it in relation to nuclear weapons and weapons of mass destruction. Indeed, thousands of space objects have been, are being, and will no doubt continue to be launched and operated for military purposes. ${ }^{38}$ Even a series of anti-satellite (ASAT) tests carried out by the U.S., Russia, China, and, more recently, India have not been condemned as contrary to the legal framework governing the use of space for peaceful purposes. ${ }^{39}$

${ }^{33} I d$. at art IV 92.

${ }^{34} I d$.

$35 I d$.

36 Id. at 91.

37 See Setsuko Aoki, Law and Military Uses of Outer Space, in RoutLedge HaNDBOoK OF Space Law 197, 201-02 (Ram S. Jakhu \& Paul Stephen Dempsey eds., 2017).

38 See USC Satellite Database, UNION OF CONCERNED SCIENTISTS, www.ucsusa.org/resources/satellite-database (last visited Dec. 16, 2019).

39 Indeed, after the most recent ASAT test in March 2019, the Ministry of External Affairs of India noted that: "India has no intention of entering into an arms race in outer space. We have always maintained that space must be used only for peaceful purposes. We are against the weaponization of Outer Space and support international efforts to reinforce the safety and security of space based assets." See Frequently Asked Questions on Mission Shakti, India's Anti-Satellite Missile Test Conducted on 27 March, 2019, InDIAN MinisTRY OF EXTERNAL AFF. (Mar. 27, 2019), https://mea.gov.in/press-releases.htm?dt1/31179/Frequ ently+Asked+Questions + on+Mission+Shakti+Indias + AntiSatellite + Missile + test + conduct ed+on+27+March+2019. Further, the Ministry noted that: "India is not in violation of any international law or Treaty to which it is a Party or any national obligation." Id.; see also Brian Weeden \& Victoria Sampson, India's ASAT Test is Wake-Up Call for Norms of Behavior in Space, SPACE NEws (Apr. 8, 2019), https://spacenews.com/op-ed-indias-asat-test -is-wake-up-call-for-norms-of-behavior-in-space/ ("India's ASAT test is wake-up call for norms of behavior in space"). 
However, unlike under traditional international law-summarized by the ruling in the Lotus case, stating that what is not expressly prohibited is permitted - this concept is not strictly applicable to the realm of outer space. ${ }^{40}$ Despite the lack of express prohibition of military uses of space, in the global commons of outer space, where the shared interests of states prevail over the individual interests of any one state, the types of activities and actions in space are limited by, e.g., the rights of other states to explore and use space, ${ }^{41}$ and the obligation to conduct activities in outer space "with due regard to the corresponding interests of all other States Parties to the Treaty." ${ }^{42}$ There is also the general obligation to conduct space activities "in accordance with international law, including the Charter of the United Nations, in the interest of maintaining international peace and security and promoting international co-operation and understanding, ${ }^{43}$ and the legality of military uses will be assessed against this criteria.

\section{The Legal Lacunae With Regard to Responsible And Peaceful USE OF OUTER SPACE}

While the space law treaties and other international instruments outline fundamental principles governing the exploration and use of outer space, to date there is no comprehensive document that lays down the legal parameters of the specific types of activities permissible in space. In particular, even though many space technologies and assets are inherently tied to military and strategic uses of outer space, there is little guidance or consensus on the extent to which military space activities are permissible on the spectrum of peacetime and times of armed conflict. Though there is a right to consult and be consulted whenever the space activities of another State in the peaceful exploration and use of outer space has potential to cause "harmful interreference," ${ }^{44}$ there is unfortunately no "precise method ... for determining, in an objective way, what constitutes harmful interference ...." 45

40 S.S. Lotus (Fr. v. Turk.), Judgement, 1927 P.C.I.J. (ser. A) No. 10, at 18-19 (Sept. 7); see also V.S. Vereshchetin, Prevention of the Arms Race in Outer Space: InTERNATIONAL LAw ASPECT, at 10-11, UNIDIR/86/08, U.N. Sales No. GV.86.02 (1986); Jonathan F. Galloway, Nuclear Winter, Ballistic Missile Defense, and the Legal Regime for Outer Space, in Proceedings of the Twenty-EIght Colloquium on the LAW of OutER SPACE, supra note 31, at 23; Ram Jakhu, Legal Issues Relating to the Global Public Interest in Space Law, 32 J. SpACE L. 31, 41-43 (2006).

${ }^{41}$ Outer Space Treaty, supra note 16, at art I.

$42 I d$. at art. IX.

43 Id. at art. III.

${ }^{44} I d$. at art IX.

45 Comm. on the Peaceful Uses of Outer Space, Survey of the Problem of Discretion Exercised by States in Interpreting Basic Legal Principles and Norms Related to Safety and Security in Outer Space: Working Paper Submitted by the Russian Federation, $\uparrow 12$, U.N. 
Currently, space activities are generally conducted under a legal regime "shaped largely by unilateral interpretation of general principles combined with informal rules of the road." 46 Though, to date, states have exercised restraint in outer space and not allowed instances of interference to escalate, "self-restraint is no substitute for effective governance mechanisms, codified in international law, especially when tensions are running high." ${ }^{47}$ As the Russian Federation recently forewarned: "The very impossibility, due to objective reasons, to reach the clear definition of a hostile intent, especially as applied to outer space, may only lead to unprecedented subjectivity in interpretations and, hence, a dramatic increase in the probability of conflicts." 48

Indeed, in what has been labelled as the highly "congested, contested and competitive" domain of activities, ${ }^{49}$ various aspects of space operations can suffer interference, or be interfered with, whether unintentionally or intentionally. Such interference may be through electromagnetic means, or:

[C]aused as a result of the following: experiments providing for a considerable alteration of the natural conditions of the space environment; operations influencing the function of equipment aboard space objects (for example, blocking or limiting the field of view of on-board optical or radio equipment); inspection operations which may lead to the threat of collision of space objects under the jurisdiction and control of different States; and operations providing for a non-coordinated physical contact of a space object under the jurisdiction and control of one State with a space object under the jurisdiction and control of another State. ${ }^{50}$

Doc. A/AC.105/2018/CRP.17 (June 21, 2018) [hereinafter Survey of the Problem of Discretion].

${ }^{46}$ Nina Tannenwald, Law Versus Power on the High Frontier: The Case for a RuleBased Regime for Outer Space, 29 YAlE J. INT'L L. 363, 378 (2004); see also Survey of the Problem of Discretion, supra note 45 , at 11.

${ }^{47}$ First Comm. of the U.N. G.A. - Disarmament and International Security, Civil Society Statement on Outer Space Security, delivered by Cesar Jaramillo, Project Ploughshares, (Oct. 16, 2015), http://ploughshares.ca/wp-content/uploads/2015/10/OuterSpace-1stCom2015.pdf.

48 Survey of the Problem of Discretion, supra note 45, at 920.

49 U.S. Dep't of Def., Office of the Dir. of Nat'l Intelligence, Nat'l Sec. Space STRATEGY: UNCLASSIFIED SUMMARY 1 (2011), https://www.dni.gov/files/documents/News room/Reports\%20and\%20Pubs/2011_nationalsecurityspacestrategy.pdf; see also Rajeswari Pillai Rajagopalan, Project Ploughsares, Outer Space: Crowded, CONGESTED, AND CONTESTED (2018), https://www.ploughshares.ca/pl_publications/outerspace-crowded-congested-and-contested.

50 See Survey of the Problem of Discretion, supra note 45, at 922 ; see generally SPACE SECURITY INDEX 2019 (Jessica West ed., 16th ed. 2019) (providing context and annual 
While harmful interference has been defined in the telecommunications context as " $[i]$ nterference which endangers the functioning of a radionavigation service or of other safety services or seriously degrades, obstructs or repeatedly interrupts a radiocommunication service, ${ }^{, 51}$ there are no objective standards as to what can be deemed to constitute endangering the functions of a space object, or what threshold must be reached to qualify as "seriously" degrading, obstructing, or repeatedly interrupting communications. Similarly, with the growing ability to conduct rendezvous and proximity operations (RPOs), which may be instrumental for debris mitigation operations, ${ }^{52}$ there is also unease as to whether such operation may be interpreted as a threat or use of force. ${ }^{53}$

\section{IV.INTERNATIONAL EFFORTS TO STRENGTHEN THE RESPONSIBLE AND Peaceful Use of Space}

Despite commending the Outer Space Treaty for identifying common interests and concerns and capturing them "in a mutually acceptable legal instrument" 54 concluded in "remarkably short time," 55 then-U.S. Secretary of State Dean Rusk noted that "[t]he treaty is not complete in all possible details," and "does not deal with all problems that may develop." 56

Five decades on, considering the continuing "fragility of the space environment and the challenges to the long-term sustainability of outer space

updates on seventeen indicators of space security); Global Counterspace Capabilities: An Open Source Assessment (Brian Weeden \& Victoria Sampson eds., 2019), swfound.org/me dia/206408/swf_global_counterspace_april2019_web.pdf (providing assessments of many national programs related to space defense).

${ }^{51}$ Int'l Telecomm. Union [ITU], Radio Regulations, art. 1.169 (2016). States must establish and operate their communications (including through space-based means) in "such a manner as not to cause harmful interference" of other States. States need only establish and operate their communications (including through space-based means) in "such a manner as not to cause harmful interference" of other States. Id. at $\S 0.4$; accord Constitution of the International Telecommunication Union art. 45, Dec. 22, 1992, T.I.A.S. 97-1026, 1825 U.N.T.S. 361.

52 See Writing the Rules on Close-Proximity Orbital Operations, European Space AGENCY (July 8, 2019), blogs.esa.int/cleanspace/2019/07/08/writing-the-rules-on-close-pr oximity-orbital-operations.

53 See, e.g., Brian Weeden, Dir. of Program Planning, Secure World Found., The Evolution of Space Rendezvous and Proximity Operations and Implications for Space Security, Presentation at the U.N. Disarmament Conference (Apr. 12, 2019), https://unidir.org/sites/ default/files/2019-12/Brian\%20WEEDEN\%20 \%20UNDCRPOApr2019.pdf.

54 Treaty on Outer Space: Hearings Before the S. Comm. on Foreign Relations, 90th Cong. 2 (1967) (statement of Hon. Dean Rusk, Sec'y of State); see also id. at 3 ("The standards developed in the Outer Space Treaty represent a balance of rights and obligations between nations who are conducting space activities and those who do not.").

$55 I d$. at 2.

${ }^{56} \mathrm{Id}$. at 4. 
activities," 57 there are obvious gaps "in the binding legal framework on outer space brought about as a result of the continuous evolution of space technology." 58 Though the space law treaties and resolutions provide a "sound and basic framework for outer space activities," ${ }^{, 9}$ since the adoption of the Moon Agreement in $1979^{60}$ there has been little appetite in the diplomatic arena for the adoption of a new binding instrument dealing with activities in outer space. ${ }^{61}$ In particular, there is a risk of "misperception, misinformation, misunderstanding and miscalculation arising from military activities in outer space," ${ }^{\prime \prime 2}$ and as a result "preventing conflicts in outer space and preserving outer space for peaceful purposes ha[s] become more relevant than ever." ${ }^{\prime \prime 3}$

Though States have acted with much restraint in outer space and largely maintained the exploration and use of space for "peaceful purposes," 64 brewing earthly tensions and the "serious legal deficit" to restrict, let alone prohibit, the weaponization of and/or extension of armed conflict into outer space may result in a situation where space itself becomes the very theater of war. The Russian Federation voiced urgent concerns about unilateral interpretations of "principles and norms of international law pertaining to safety and security in outer space," ${ }^{, 66}$ particularly in a domain where concepts such as what constitute "harmful interference" are ill-defined and

57 G.A. Res. 73/91, International Cooperation in the Peaceful Uses of Outer Space, $\uparrow 8$ (Dec. 18, 2018) [hereinafter ICPUOS].

${ }^{58}$ Long Term Sustainability Guidelines, supra note 11, at 199.

${ }^{59}$ Id. at 197.

60 Though the space law treaties and resolutions provide a "sound and basic framework for outer space activities," since the adoption of the Moon Agreement in 1979, there has been little appetite in the diplomatic arena ...." See Moon Agreement, supra note 24, at 3 .

61 The Moon Agreement was the last treaty dealing with activities in space to be adopted. See Moon Agreement, supra note 24, at 3. The most recent treaty to be proposed failed to gain international support. See Letter dated Feb. 12, 2008 from the Permanent Representative of the Russian Federation and the Permanent Representative of China to the Conference on Disarmament addressed to the Secretary-General of the Conference Transmitting the Russian and Chinese Texts of the Draft Treaty on Prevention of the Placement of Weapons in Outer Space and of the Threat or use of Force Against Outer Space Objects (PPWT), U.N. Doc. CD/1839 (Feb. 29, 2008) [hereinafter U.N. Doc. CD/1839 ]; Meetings Coverage, Raising Alarm over Possible Space Wars, First Committee Delegates Explore Ways to Build New Order for Preventing Celestial Conflict, Confrontation, GA/DIS/3609 (Oct. 24, 2018), https://www.un.org/press/en/2018/gadis3609.doc.htm.

${ }^{62}$ Long Term Sustainability Guidelines, supra note 11, at 49.

${ }^{63} \mathrm{Id}$. at 51 .

64 Tannenwald, supra note 46, at 409.

65 Jackson Nyamuya Maogoto \& Steven Freeland, From Star Wars to Space Wars-The Next Strategic Frontier: Paradigms to Anchor Space Security, 33 J. AIR \& SpACE L. 10, 36 (2008).

66 Survey of the Problem of Discretion, supra note 45, at 1 . 
may lead to "conflict and near-to-conflict situations in outer space." ${ }^{\prime 67}$ What is needed is a better awareness of the nature, positions, and trajectories space objects and activities in outer space, ${ }^{68}$ as well as clearer standards and agreed set of rules on launch, on-orbit operations, and post-mission disposal of space objects to increase overall transparency, as well as to prevent and diffuse possible escalating tensions in space. ${ }^{69}$

To date, attempts at addressing the wider issue of military uses of space and space security have included a U.N. General Assembly resolution aimed at deterring an arms race in outer space, ${ }^{70}$ a proposed Sino-Russian treaty aimed at the prevention of the placement of weapons and prohibiting the threat or use of force in space, ${ }^{71}$ the development of transparency and confidencebuilding measures (TCBMs) relating to space activities, ${ }^{72}$ and attempts to clarify norms of behaviour in space. ${ }^{73}$ Further, joint ad hoc meetings of the First (Disarmament and International Security) and Fourth (Special Political and Decolonization) Committees of the UN General Assembly were convened in 2015 and 2017 with the aim of addressing "possible challenges to space security and sustainability," ${ }^{, 4}$ and a Group of Governmental Experts (GGE) was established to consider practical measures for the prevention of an arms race in outer space and to "make recommendations on substantial elements of an

${ }^{67} I d$. at $9 \uparrow$ 6, 12 ("Finding a precise method to be used for determining, in an objective way, what constitutes harmful interference does not seem a fairly easy thing to do.")

68 This can be encapsulated under the concept of "space situational awareness" and corollary concept of space traffic management. See Secure World Foundation, Space SustainABILITY: A PracticAl GuIDE 16-17 (2018), swfound.org/media/206407/swf_spac e_sustainability_booklet_2018_web.pdf.

${ }^{69}$ Long-Term Sustainability Guidelines, supra note 11, at 949.

${ }^{70}$ G.A. Res. 74/32, supra note 9.

${ }^{71}$ U.N. Doc. CD/1839, supra note 61; see also G.A. Res. 74/34, No First Placement of Weapons in Outer Space (2019).

72 See U.N. Secretary General, Group of Governmental Experts on Transparency and Confidence-Building Measures in Outer Space Activities, U.N. Doc. A/68/189 (July 29, 2013). For the latest UNGA resolution, see G.A. Res.74/67, Transparency and ConfidenceBuilding Measures in Outer Space Activities (Dec. 12, 2019).

${ }^{73}$ EU Proposal for an International Space Code of Conduct, Draft, EuROPEAN UNION EXTERNAL ACTION (Mar. 31, 2014), www.eeas.europa.eu/non-proliferation-and-disarmam ent/pdf/space_code_conduct_draft_vers_31-march-2014_en.pdf.

${ }^{74}$ Press Release, Gen. Assembly, As Fourth, First Committees Hold Joint Meeting, Speakers Stress Need for Holistic Handling of Outer Space Security, Sustainability, U.N. Press Release GA/DIS/3531 (Oct. 22, 2015); Press Release, Gen. Assembly, Raising Alarm over Possible Space Wars, First Committee Delegates Explore Ways to Build New Order for Preventing Celestial Conflict, Confrontation, U.N. Press Release GA/DIS/3609 (Oct. 24, 2018). 
international legally binding instrument on the prevention of an arms race in outer space." ${ }^{~} 75$

Sadly, none of these diplomatic and multilateral efforts proved effective or lasting to divert away from the worrying trend of expanding space militarisation, possible space weaponization, and potential conflicts (wars) in space. Indeed, at the latest UNCOPUOS meeting in 2019, the view was expressed "that the absence of conflicts in space in the past could not be regarded as a guarantee of peace, in particular in an era in which new actors were entering the space arena." ${ }^{.76}$ Urgently needed are considerations of "ways and means of maintaining outer space for peaceful purposes and its consideration of the broader perspective of space security and associated matters that would be instrumental in ensuring the safe and responsible conduct of space activities $\ldots, ., 77$

\section{V.WAys and Means of Maintaining OUter Space for Peaceful PURPOSES}

The lack of diplomatic will, and at times inability, to address issues related to space activities in general and matters of space security in particular, has resulted in repeated calls to find "ways and means of maintaining outer space for peaceful purposes" and addressing the broader issue of space security and the "the safe and responsible conduct of space activities." 78 Such efforts have been ongoing for at least two decades. ${ }^{79}$ Such efforts will invariably persist due to various diplomatic efforts (outlined above) that have been tried and tested without much avail.

Though perspectives on the substantive means and ways of maintaining outer space for peaceful purposes differ ${ }^{80}$ there is undeniable consensus that the international legal framework established by the UN space law treaties and resolutions must underpin all undertakings in the exploration and use of space, irrespective of whether such activities are civilian in nature or have a military or security bearing. ${ }^{81}$

75 G.A. Res. 72/250, ๆ 3 (Jan. 12, 2018). For the latest report, see U.N. Secretary-General, Group of Governmental Experts on Further Practical Measures for the Prevention of an Arms Race in Outer Space, U.N. Doc. A/74/77 (Apr. 9, 2019).

${ }^{76}$ Long-Term Sustainability Guidelines, supra note 11 , at 954.

77 Id. at 42.

78 Press Release, Fourth Committee, Using Outer Space for Peaceful Purposes Can Contribute to Implementation of Millennium Declaration, Chairman Says, As Fourth Committee Begins Debate, U.N. Press Release GA/SPD/321 (Oct. 17, 2005).

79 See, e.g., G.A. Res. 54/67, 129 (Feb. 11, 1999).

${ }^{80}$ See generally Comm. on the Peaceful Uses of Outer Space, Rep. of the Legal Subcomm. on Its Sixty-Second Session, U.N. Doc. A/74/20 (2019).

${ }^{81}$ ICPUOS, supra note 57 , at 95. 
Presented below are two recent initiatives and, arguably, breakthroughs at the international level that serve to produce instruments to ensure that the governance of outer space continues under the international rule of law and is driven by the interests of all of humankind. One initiative is the top-down diplomatic effort that resulted in the drafting and adoption of the UN Longterm Sustainability Guidelines by the UNCOPUOS; the second is the civil society initiative in the drafting of the McGill Manual on International Law Applicable to Military Uses of Outer Space.

\section{VI.THE LONG-TERM SUSTAINABILITY GUIDELINES}

Writing at the dawn of the Space Age, Myres S. McDougal and Leon Lipson noted that the mode of the regulation of space activities cannot be "be charted with any precision. $" 82$ Much of this is due to the very nature of the domain, which unlike any other, is an arena where military and non-military (civilian and commercial) interests and activities intercept and have always been intertwined.

Even so, by and large the governance of outer space has gone through phases that last approximately two decades, ${ }^{83}$ beginning with the multilateral treaty process and adoption of the five UN space law treaties from the 1960s to the 1980s, which was followed up with the advent of UN principles dealing with specific technical applications of space from the 1980 s to the $2000 \mathrm{~s} .{ }^{84}$ The 2000s to date have been marked by the adoption of General Assembly resolutions and guidelines on matters such as TCBMs and the prevention of an arms race in outer space outlined in the previous section. The latest phase culminated with the rare and historic adoption of the Guidelines for the Longterm Sustainability of Outer Space Activities of the Committee on the Peaceful Uses of Outer Space (Long-Term Sustainability Guidelines). ${ }^{85}$

${ }^{82}$ Myres S. McDougal \& Leon Lipson, Perspectives for a Law of Outer Space, 52 Ам. J. INT'L L. 407, 430 (1958).

83 This was highlighted by Mr. Niklas Hedman, Chief Policy \& Legal Affairs section of the United Nations Office for Outer Space Affairs, at the APSCO TUBITAK UZAY Space Law Training Course, 18-21 September 2019, Istanbul, Turkey. Niklas Hedman, Chief Policy \& Legal Affairs, United Nations Office for Outer Space Affairs, Lecture at the APSCO TUBITAK UZAY Space Law Training Course, in Istanbul, Turkey (Sept. 2019).

${ }^{84}$ See G.A. Res. 37/92, supra note 25; G.A. Res. 41/65, supra note 25; G.A. Res. 47/68, supra note 25; G.A. Res. 62/101 (Dec. 17, 2007); Comm. on the Peaceful Uses of Outer Space, Rep. of the Legal Subcomm. on Its Sixty-Second Session, U.N. Doc. A/62/20 (2007); G.A. Res. 68/74 (Dec. 11, 2013).

${ }^{85}$ Long-Term Sustainability Guidelines, supra note 11, at 50. 
The Long-Term Sustainability Guidelines were adopted by consensus as a result of close to a decade of intense discussions ${ }^{86}$ on a set of voluntary guidelines for space actors to ensure space:

remain[s] an operationally stable and safe environment that is maintained for peaceful purposes and open for exploration, use and international cooperation by current and future generations, in the interest of all countries, irrespective of their degree of economic or scientific development, without discrimination of any kind and with due regard for the principle of equity. ${ }^{87}$

The Guidelines have been hailed as a breakthrough in international transparency and norm-building. For the first time since the adoption of the Moon Agreement four decades ago, there is now a compendium of internationally agreed measures and practices to ensure the long-term sustainability of space activities and to enhance the safety of space operations. Integral to the Guidelines is fulfilling the objectives of the Declaration of Legal Principles and Outer Space Treaty to ensure that outer space can be explored and used by current and future generations for peaceful purposes and in the interest of all humankind. ${ }^{88}$ Underpinning the Guidelines is the consensus that the exploration and use of outer space, including the Moon and other celestial bodies, remains "the province of all (hu)mankind," 89 and that activities of States in outer space be carried out in accordance with international law, including the Charter of the United Nations, thus affirming the principles contained in Article III of the Outer Space Treaty. ${ }^{90}$

The Guidelines address a number of policy, regulatory, operational, technical and capacity-building aspects of space activities, ${ }^{91}$ and apply to ongoing or planned activities conducted by States, international organizations or nongovernmental entities. ${ }^{92}$ The Guidelines are drafted in way that make them relevant "to all phases of a space mission, including launch, operation and end-of-life disposal." 93

To date, there have been twenty-one guidelines adopted on, among other matter, enhancing the national regulation and supervision of national space

\footnotetext{
${ }^{86}$ See generally Peter Martinez, Development of an International Compendium of Guidelines for the Long-Term Sustainability of Outer Space Activities, 43 SPACE POL'y 13 (2018).

${ }^{87}$ Long-Term Sustainability Guidelines, supra note 11, at 50 व 4.

${ }^{88} \mathrm{Id}$. at $50-5195$.

89 Outer Space Treaty, supra note 16, at art. I; Long-Term Sustainability Guidelines, supra note 11 , at 51 \8.

${ }^{90}$ Long-Term Sustainability Guidelines, supra note 11, at 51 ๆ 7.

91 Id. at 51 व 11 .

92 Id.

${ }^{93} \mathrm{Id}$.
} 
activities, ${ }^{94}$ improving the timely practice of registration, ${ }^{95}$ and enhancing the safety of space operations, ${ }^{96}$ especially information exchange on space objects and events. ${ }^{97}$ There are further guidelines on enhancing the sharing of space debris monitoring information, ${ }^{98}$ sharing space weather data and forecasts and developing space weather models, ${ }^{99}$ and for promoting and supporting information exchange and capacity-building. ${ }^{100}$ Seven guidelines, pertaining to more politically sensitive and divisive issues, such as the commitment to conducting space activities solely "for peaceful purposes" 101 and measures to identify and mitigate risks to terrestrial infrastructure that support space operations, ${ }^{102}$ are to be discussed further with the aim of reaching international consensus in the years to come.

While laudable, the Guidelines are exactly as the name suggests: guidelines that are to be implemented "to the greatest extent feasible and practicable" and according to the "respective needs, conditions and capabilities" of the states or international organizations concerned. ${ }^{103}$ Thus, the Guidelines are "voluntary and not legally binding under international law." ${ }^{104}$ Further, it is expressly stated that the Guidelines do not "constitute a revision, qualification or reinterpretation of [applicable international law] principles and norms," 105 which may undermine their status and value.

However, it must be recognized that even if states and international organizations voluntarily implement or refer to the Guidelines, the international community may see greater convergence of practices and the adoption of regulations and policies in line with the Guidelines. Such convergent practices, and the adoption of regulations and policies that are inspired by the Guidelines, may support the emergence of general practice that is "sufficiently widespread and representative, as well as consistent." 106 Such general practice

${ }^{94}$ Id. at $\S$ II (A)(1)-(3), at 54-56.

${ }^{95} I d$. at $\S$ II $(\mathrm{A})(5)$, at $57-59$.

96 Id. at $\S$ II (B), at 59-66.

${ }^{97} \mathrm{Id}$. at $\S$ II (B)(2)-(5), at 60-62.

${ }_{98}$ Id. at $\S$ II (B)(3), at 60; see also id. § II (B)(8), at 64.

99 Id. § II (B)(6)-(7), at 62-64.

100 Id. $\S$ II (C)(1)-(4), at 66-68.

101 Survey of the Problem of Discretion, supra note 45 , at 97.

102 Id. at 4, §§ 18-19.

${ }^{103}$ Long-Term Sustainability Guidelines, supra note 11, at 16.

104 Id. at 15.

$105 \mathrm{Id}$.

106 Int'l Law Comm'n, Rep. on the Work of Its Sixty-Eighth Session, U.N. Doc. A/71/10, at 77 (2016). 
need not be "absolutely rigorous," 107 and may go a long way to creating practice that may eventually be valuable in the identification of custom. ${ }^{108}$

\section{THE MILAMOS PROJECT}

As alluded to earlier, though space activities must be conducted in accordance with the international rule of law, obviously not all international law would apply to space activities. ${ }^{109}$ As Lachs noted, many domains of international law would acquire a "new dimension" in regulating the conduct of states in outer space and would therefore warrant "a more extensive interpretation." 110 Again, the Russian Federation described the problem succinctly and underlined that "analysis or characterization by a State of another State's behaviour most often does not reflect the manner in which that State judges its own behaviour of essentially the same kind. Such double standards may result in a situation where events develop according to a threatening scenario." 111 Thus, there is a need to objectively clarify the rules of international law applicable to military space activities conducted during peacetime, including in times posing challenges to peace. ${ }^{112}$

The implications of certain activities that interfere with the rights of other States may lead to internationally wrongful acts and warrant different responses that, ${ }^{113}$ in order to ensure sustainable, responsible and peaceful use of

107 Military and Paramilitary Activities in and Against Nicaragua (Nicar. V. U.S.), Judgement, 1986 I.C.J. 14, $\uparrow 186$ (June 27).

108 For more on the elements of custom, see Ram Jakhu et al., The Sources of International Space Law: Revisited, 67 J. AIR \& Space L. 606, 623 (2018). As Daniel Thurer describes it, soft law instruments, such as the Long-Term Sustainability Guidelines, represent "a complex of norms lacking binding force, but producing significant legal effects nevertheless." Daniel Thurer, Soft Law, - 37, in MAX Planck ENCYClopedia OF Public InTERnAtional Law (2009); see also Steven Freeland, The Role of 'Soft Law' in Public International Law and Its Relevance to the International Legal Regulation of Outer Space, in Soft Law in Outer Space: The Function of Non-Binding Norms in InTERnational SpaCE LAW 9-30 (2012); Jean-Francois Mayence, The European Union's Initiative for a code of Conduct on Space Activities: A Model of Soft Law for Outer Space?, in SoFT LAW in Outer Space: The Function of Non-Binding Norms in International Space Law 343 (2012).

109 There may be some rules that do not apply, such as lex specialis rules that govern “specific environments." See LAChS, The LAW OF Outer SPACE, supra note 13, at 13.

$110 \mathrm{Id}$. at 14.

111 Survey of the Problem of Discretion, supra note 45, at 915.

112 The vision of the MILAMOS Project is to "develop, within a period of three years, a manual that objectively articulates and clarifies existing international law applicable to military uses of outer space in time of peace, including challenges to peace." See Manual on International Law Applicable to Military Uses of Outer Space, McGILL, https://www.m cgill.ca/milamos/ (last visited Feb. 5, 2020).

113 Int'l Law Comm'n, Rep. on the Work of Its Fifty-Third Session, Draft Articles on Responsibility of States for Internationally Wrongful Acts, pt. 2, U.N. Doc. A/56/10 
outer space, may well differ according to the circumstances and the severity of the interference. The maintenance of international peace and security, on Earth as well as in space, must distinguish between what the International Court of Justice held in Nicaragua are "the most grave forms of the use of force (those constituting an armed attack) from other less grave forms." 114

The Articles on State Responsibility, codified by the International Law Commission and adopted by the U.N. General Assembly, ${ }^{115}$ confirm that the international legal regime is governed by a framework to adjudge the responsibility of States for wrongful acts ${ }^{116}$ and describe circumstances when wrongfulness can be precluded, ${ }^{117}$ such as in the event of necessity ${ }^{118}$ or self-defence. ${ }^{119}$ Countermeasures may be taken, also in the space context, as long as it is in accordance with international law and the UN Charter to refrain from the threat or use of force, ${ }^{120}$ and so far as the countermeasure is commensurate to the injury suffered and subject to other conditions considering the gravity of the triggering wrongful act and rights affected. ${ }^{121}$

By capturing the applicable customary law in black-letter rules and providing evidence of State practice and opinio juris to support the existence of such customary norms, manuals have historically proven useful to reach international consensus on the legality of activities in domains on which "an international treaty, which might perhaps be premature or at least very difficult to obtain." 122 The space domain, particularly in relation to discussing and reaching consensus on the rules surrounding military space activities and activities that have implications for space security, is a realm of regulation that is wellsuited for the manual process.

(2001), reprinted in [2001] 2 Y.B. INT'L L. COMM'N 32, U.N. Doc. A/CN.4/SER.A/2001/Add.1 (Part 2) [hereinafter Articles on State Responsibility].

114 Military and Paramilitary Activities in and Against Nicaragua (Nicar. v. U.S.), Judgment, 1986 I.C.J. 14, 191 (June 27); see also Case Concerning Oil Platforms (Iran v. U.S.), Judgment, 2003 I.C.J. 161, \64 (Nov 6).

115 G.A. Res. 56/83, Responsibility of States for Internationally Wrongful Acts (Jan. 28, 2002).

116 An international, wrongful act must be: i) attributable to the State under international law; and ii) constitute the breach of an international obligation of the State. See Articles on State Responsibility, supra note 113, at art. 2.

117 See id.

$118 I d$. at art. 25.

119 Id. at art. 21.

120 UN Charter art. 2, 9 ; see also Articles on State Responsibility, supra note 113, at art. 50(1)(a).

121 See generally Articles on State Responsibility, supra note 113, at ch. II; see also Survey of the Problem of Discretion, supra note 45, at 10.

122 The Laws of Armed Conflicts: A Collection of Conventions, Resolutions, And Other Documents, Preface (Dietrich Schindler \& Jiri Toman eds., 1988). 
The contribution and value of manuals have moreover been affirmed on occasions by international courts and tribunals, ${ }^{123}$ with the International Criminal Court deeming manuals as "provid[ing] the most useful guidance on the applicable law," and as providing the "useful expression of the crystallisation" of the law. ${ }^{124}$ There have been various non-governmental efforts to objectively clarify the application of the law in the other frontiers. The process and success of the San Remo Manual on International Law Applicable to Armed Conflict at Sea, ${ }^{125}$ the Harvard Manual on International Law Applicable to Air and Missile Warfare, ${ }^{126}$ and the Tallinn Manual on International Law Applicable to Cyber Warfare ${ }^{127}$ demonstrate how international experts and engagement with governments can produce non-official interpretation and clarification of the law while avoiding many of the challenges inherent in multilateral negotiations among states. Though these manuals deal with the application of the law of armed conflict or warfare in particular domains, it must be underlined that "manuals today do not limit their coverage just to the law of armed conflict." 128

The McGill Manual is the first of its kind to address the legality of a range of issues that have a bearing on military activities in outer space. Doing so will contribute to the progressive development of international law and foster international peace and security and the sustainability of outer space, which is in the interest of all States, and is indeed a goal of all humanity.

Launched in May 2016, and having gathered the involvement of dozens of legal and technical subject-matter experts from institutions across the globe, ${ }^{129}$ the MILAMOS Project crucially defines the legality and scope of responsible behavior in situations that fall short of armed conflict. The

123 Prosecutor v. Tadić, Case No. IT-94-1-1, Decision on Defence Motion for Interlocutory Appeal on Jurisdiction, \99 (Int'l Crim. Trib. for the Former Yugoslavia Oct. 2, 1995); U.N. Panel of Inquiry on the Gaza Flotilla Incident of May 31, 2010, Rep. of the SecretaryGeneral's Panel of Inquiry on the 31 May 2010 Flotilla Incident, $\mid 157$ (Sept. 2011).

124 In'tl Criminal Court, Office of the Prosecutor, Situation on Registered Vessels of Comoros, Greece and CAmbodia: Article 53(1) Report $\mid 31$ (2014), https: //www.icc-cpi.int/iccdocs/otp/otp-com-article_53(1)-report-06nov2014eng.pdf.

125 San Remo Manual of International Law Applicable to Armed Conflict at SEA (Louise Doswald Beck ed., 1994).

126 Program on Humanitarian Policy and Conflict Research at Harvard Univ., Harvard Manual of International Law Applicable to Air and Missile Warfare (2009), https://reliefweb.int/sites/reliefweb.int/files/resources/8B2E79FC145BFB3D4925 76E00021ED34-HPCR-may2009.pdf.

127 NATO Coop. Cyber Def. Ctr. of Excellence, Tallinn Manual on the InTERNATIONAL LAW APPLICABLE TO CyBER WARFARE (2013).

128 Earle A. Partington, Manuals on the Law of Armed Conflict, 1 10, in MAX PLANCK EnCyClopedia of Public International LaW (2016); see, e.g., Leuven MANuAL on the International LaW Applicable to Peace Operations (Terry D. Gill et al. eds., 2017).

129 Our People, McGiLl UNIV., www.mcgill.ca/milamos/our-people (last visited Mar. $30,2020)$. 
MILAMOS Project also explains the legal consequences that exist for states that breach their international obligations toward other states and the international community as a whole. Such a manual is essential in clarifying how international legal principles and norms such as interference, intervention, and the threat or use of force apply in outer space or to space activities, so as to avoid unilateral interpretations of the law and reduce the risk of "misperception, misinformation, misunderstanding and miscalculation arising from military activities in outer space." 130 Such clear statements and interpretations of the law by neutral experts will be crucial to ensure that all space activities, conducted by a State or space operator, are conducted in accordance with fundamental tenets of international law.

Acknowledgement by States and international experts in the legal domain of these fundamental concepts amount to a significant transparency and confidence-building measure, which would in turn help to reduce the likelihood of conflict in space. The successful completion of a manual with the input of eminent authors, experts and recognized stakeholders in space activities will provide states and space operators with clear statements and objective interpretations of the law as it is (lex lata).

To date, the MILAMOS Project has gathered international renown and has been presented at various venues across the globe. More recently, in June 2018, at the symposium organized to mark the fiftieth anniversary of the first United Nations Conference on the Peaceful Uses of Outer Space (UNISPACE+50), the MILAMOS Project was highlighted as a prime example of the role that civil society institutions can play to bring together various actors and stakeholders involved in the exploration and use of outer space and foster dialogue and consensus on challenging issues pertaining to space law. ${ }^{131}$ Reflecting the remarkable standing of the MILAMOS Project, in October 2018 the rule-drafting and consensus-forming process, the latest developments, and progress surrounding the work of the Manual were presented to the delegates of the Sixth Committee of the United Nations General Assembly and of the United Nations Committee on Peaceful Uses of Outer Space (UNCOPUOS). ${ }^{132}$ In September 2019, the MILAMOS Project was presented at the Second United Nations Conference on Space Law and Policy as a viable means to strengthen the long-term use and sustainability of outer space. ${ }^{133}$

130 Long-Term Sustainability Guidelines, supra note 11, at 949.

131 MILAMOS Project Presented at UNISPACE+50, MCGILL UnIV. (June 18, 2018), ww w.mcgill.ca/milamos/news-and-updates\#UNISPACE50.

${ }^{132}$ MILAMOS Project Director Ram Jakhu Present Before Delegates of the UN Sixth Committee, McGILL UNIV., www.mcgill.ca/milamos/news-and-updates\#UNGA (last visited Mar. 30, 2020).

133 See Kuan-Wei Chen, The Role of International Manuals in Contributing to the Peaceful and Safe Use of Outer Space, Presentation at the UN/Turkey/APSCO Conference on Space Law and Policy (Sept. 20, 2019), www.unoosa.org/documents/pdf/spacelaw/activities/2019/T1-3-KC_Contributions_of_Manuals_to_Peaceful_and_Safe_Use_of_Space_C 


\section{VIII.CONCLUSION}

At the adoption of the Outer Space Treaty in 1967, then-U.S. President Lyndon Johnson famously declared that "[n]o one may use outer space or celestial bodies to begin a war." ${ }^{134}$ Noting the "successful identification of common interests and their expression in a mutually acceptable legal instrument" "135 that was concluded in "remarkably short time," 136 then-Secretary of State Dean Rusk underlined the Treaty's success "in substantial measure in establishing the necessary standards for reducing the dangers of military conflict in outer space" and the necessity of cooperation if "the world is going to escape destruction by conflict." "137 These words ring true over half a century since the adoption of the single most crucial international instrument that has prevented conflict in space.

As one person succinctly highlighted at the UNCOPUOS, the "absence of conflicts in space in the past could not be regarded as a guarantee of peace."138 Though military and strategic interests have been integral to the exploration and use of outer space from the very beginning, the ICRC has unequivocally stated that as with any new means or methods of warfare, "the weaponization of outer space is not inevitable but is a choice" that would increase the probability of armed conflict in outer space. ${ }^{139}$ Due to the devastating consequences and humanitarian implications of an armed conflict in space, all states that are reliant on the space infrastructure must avoid further weaponization and trends that increase the likelihood of conflict. Indeed, the choice to fight a war in space is one that even the United States, ${ }^{140}$ and all other States, do not wish to engage in for "no one wins if war extends into space."

onference_use.pdf

134132 Cong. ReC. 2,782 (1967) (letter of transmittal to the U.S. Senate by President Lyndon Johnson).

135 Treaty on Outer Space: Hearings Before the S. Comm. on Foreign Relations, 90th Cong. 2-3 (1967) (Statement of Hon. Dean Rusk, Secretary of State) ("The standards developed in the Outer Space Treaty represent a balance of rights and obligations between nations who are conducting space activities and those who do not.").

$136 \mathrm{Id}$. at 2.

137 Id. at 4.

138 Long-Term Sustainability Guidelines, supra note 11, at 95.

139 Group of Governmental Experts on Further Practical Measures for the Prevention of an Arms Race in Outer Space, Humanitarian Consequences and Constraints Under International Humanitarian Law (IHL) Related to the Potential Use of Weapons in Outer Space, Working Paper Submitted by the International Committee of the Red Cross (ICRC), $1913-$ 14, U.N. Doc. GE-PAROS/2019WP.1 (2010).

${ }^{140}$ Lee Billings, War in Space May Be Closer Than Ever, ScI. Am. (Aug. 10, 2015), www.scientificamerican.com/article/war-in-space-may-be-closer-than-ever (quoting General John Hyten, the head of the U.S. Air Force Space Command).

${ }^{141}$ Lara Seligman, No One Wins if War Extends into Space, Foreign Pol'y (Dec. 4, 2019), foreignpolicy.com/2019/12/04/thomas-james-interview-space-force-commander-n o-one-wins/. 
In light of the inability to reach binding international agreement to secure space security and set ground rules for the military uses of outer space, the UN Long-Term Sustainability Guidelines and the MILAMOS Project presented in this Article are innovative and viable ways and means which will go a long way to strengthen the responsible and peaceful use of outer space. 